VI. The committee agrees, that whatever may be the ultimate ruling on the last point, there are many practical difficulties in the way of recognizing names proposed as in case 2 , so that even were such names held to be available, many of them would have to be rejected as of uncertain application. It is perfectly clear that no rules will absolve an author from using his critical judgment in the several cases that come before him; and after the rules have declared a name available from their standpoint, it may be a long way to availability from the standpoint of practical identification.

The committee is greatly indebted to Dr. C. W. Stiles, the secretary of the International Commission on Zoological Nomenclature, for a full and luminous discussion of the matters in dispute.

H. T. FERNALD

T. D. A. Cockerell

E. P. FELT

\section{SOCIETIES AND ACADEMIES}

THE MICHIGAN ACADEMY OF SCIENCE

THE 15th annual meeting of the academy was held at Ann Arbor, Mich., March 31 and April 1 and 2. The meeting was made the occasion of a Darwin Centenary Celebration, and the Research Club of the University of Michigan and the Michigan Schoolmasters' Club cooperated with the academy in furnishing special programs. The papers presented were as follows:

\section{Program of the Darwin Celebration}

Darwin Program of the Academy of Science.

Address of the president: "The Beginnings of Life from the View-point of a Bacteriologist," Dr. Charles E. Marshall.

"Theories of Animal Coloration, especially Warning Coloration," Professor Jacob Reighard.

"A Contribution to the Theory of Orthogenesis," Dr. Alexander Ruthven.

"American Paleontology and Neo-Lamarckism," Professor E. C. Case.

"The Mutation Theory from the Botanical View-point," Dr. Henri de Leng Hus.

The above papers were, for the most part, devoted to a discussion of the methods of evolution, from the standpoint of the original work of the speakers.

Public address under the auspices of the Research Club of the University of Michigan: "Darwinism and Paleontology," Professor W. B. Scott, Princeton University. In this lecture Professor Scott reviewed the evidence of evolution furnished by paleontology, and discussed the character of the evidence, using as illustrations the horse, camel, rhinoceros and other mammalian series.

Joint Session of the Science Teachers Section of the Academy and the Biological Section of the Schoolmasters' Club, S. D. Magers, chairman. The Effect of the Darwin Doctrines:

"On Biology," Professor C. B. Davenport.

"On Psychology," Professor N. A. Harvey.

"On Education," President E. G. Lancaster.

"On Religion," Rev. Carl S. Patton.

As indicated by the titles, the papers presented at this meeting were concerned with the influence of the Darwinian theories upon the different fields of thought represented by the speakers.

\section{Regular Program}

Section of Agriculture, A. J. Patten, vice-president. (Held at the Michigan Agricultural College, April 14.)

"Some Reminiscences of the Attitude of Harvard Professors toward Darwin's Work," W. J. Beal.

"Darwin's Influence on Plant Breeding," H. J. Eustace.

“Darwin's Influence on Animal Breeding," A. C. Anderson.

"Further Experimental Work on the Interaction of Plant Roots," J. B. Dandeno.

"Advanced Methods in Milk Analysis," W. E. Robison.

"A Discussion of the Value of Raw Rock Phosphate for Fertilizing Purposes," A. J. Patten.

Section of Botany, Wm. E. Praeger, vice-president. "Osmotic Theories, with Special Reference to van't Hoff's Law," J. B. Dandeno.

"Investigation on Bordeaux Mixture," J. B. Dandeno.

"The Rapid Extension of Weeds in Michigan," W. J. Beal.

"Origin of the Flora of Local Peat Bogs," Geo.

P. Burns.

"The Effect of Longitudinal Compression upon the Production of Mechanical Tissue in Stems,"

L. H. Pennington.

"The Plasticity of Some of the Compositæ around Ann Arbor," S. Alexander.

"The Phytogeographical Relations of the Mount Ktaadn Flora," L. H. Harvey.

"Notes on Plant Pathology," J. B. Pollock.

"The Carbon Nutrition of a Fungus," Rose M. Taylor and J. B. Pollock.

"The Culture of Fern Prothallia," Elizabeth D. Wuist. 
“ Unreported Michigan Fungi for 1908," C. H. Kauffiman.

"Methods of Sterilizing Seeds," R. de Zeeuw.

"Growth of Water Cultures in Various Solutions," N. W. Scherer.

"Variations in Leaves and Flowers," Henrı de Leng Hus.

"Variations in the Dimensions of the Tracheids of Picea excelsa," S. M. Hamilton and W. H. Ramson.

Section of Geology and Geography, Wm. H. Hobbs, vice-president.

"The Comparison of the Loess Deposits of Europe and America," Frank Leverett.

"The Story of Niagara told in Photographs,"

Frank B. Taylor.

"An Agerite-Oligoclase Aplite from the Lake Superior Region," Alfred C. Lane.

"The Differentiation toward the Most Fusible

Mineral (Augite) in Non-hydrous Magmas,"

Alfred C. Lane.

"Occurrence of Sulphur in Sicily," W. F. Hunt.

"The Physiography of an Ancient Delta Region in Texas," E. C. Case.

"Some New Occurrences of Iodyrite," C. W. Cook.

"The Use of Crystallography in the Identification of Commercial Chemical Compounds," E. H. Kraus.

"The Iron Ranges of the Nipigon Region, Ontario," O. Bowles.

"The Iron Ores of Spring Valley, Wisconsin,"

R. C. Allen.

"New Apparatus for Instruction in Geology," Wm. H. Hobbs.

"The Raw Materials for Portland Cement in Alabama, together with Analyses," W. F. Cooper and Delos Fall.

"The Flint Water Supply," Alfred C. Lane and

F. Harlan Bretz.

"Stadia of the Wisconsin Glaciation in North America," Frank Leverett.

Section of Sanitary Science, E. C. L. Miller, vicepresident.

"Examination of a Commercial Ferment," W.

E. Forsythe.

"The Standardization of Contact Insecticides,"

H. C. Hamilton.

"The History of the Sausage," Floyd W. Robison.

"The Organization of the Anti-tuberculosis Work," V. C. Vaughan, Sr.

"Situs Viscerum Transversus," Hugo A. Freund.

"Concerning So-called Agglutinoids," E. C. L. Miller.
"Staining of Sections by the Romanowsky Method," F. J. MeJunkin.

"A Demonstration of the Effect of Alcohol on Gastric Digestion," S. D. Magers.

"Negri Bodies as a Diagnostic Factor in Rabies," Jas. G. Cumming.

"The Undetected Cases of Diphtheritic Infection of the Nose," Preston M. Hickey.

"Human Myiosis," A. W. Blain.

"The Wassermann Reaction," Jas. G. Cumming.

"Trypanosome Infection through Mucous Membranes," W. A. Perkins.

"Diagnosis Leishmania Infantum by Cultural Methods," F. G. Novy and P. A. Schule.

"Leishmaniasis," F. G. Novy.

Section of Zoology, Dana B. Casteel, vice-president.

"Notes on Michigan Reptiles and Amphibians," A. G. Ruthven.

"Notes on the Crayfish of Michigan," A. S. Pearse.

"The Early Development of Neurofibrillæ in Rana pipiens and Ambystoma punctatum," Hansford MacCurdy.

"Amitosis in the Nervous Tissues of Cryptobranchus," Q. O. Gilbert.

"On the Way in which Nematocysts Function," O. C. Glaser.

"Effects of Centrifugal Force upon the Embryonic Development of Some Chrysomelid Beetles," R. W. Hegner.

"The Germ Cell Determinants in Beetles," R. W. Hegner.

"Some Light Responses in the Jelly-fish, Gonionemus," Louis Murbach.

"Reaction of Amphibians to Light," A. S. Pearse.

"Method of Preserving Material for Vertebrate Dissection," J. J. Myers.

"Effects of Pressure upon the Embryonic Development of Some Chrysomelid Beetles," R. W. Hegner.

"The Distribution of the Unionidce of Alabama," Bryant Walker.

"Notes on a Double Snail (Campeloma -)," Hansford MacCurdy.

"Notes on the Skeleton of Chamoleon cristatus Stutchb.," E. C. Case.

"Locality Memory in the Woodchuck," Jacob Reighard.

"Key to Michigan Gasteropods," H. B. Baker.

"Pearl Organs: A Secondary Sexual Character not Easily Explained through Use," N. H. Stewart.

Alexander G. RUthven 